\title{
APUNTES PARA LA INTERPRETACIÓN CONSTITUCIONAL DEL CÓDIGO PROCESAL PENAL
}

\author{
VÍCTOR BURGOS MARIÑOS*
}

\begin{abstract}
Resumen
En el texto del nuevo Código Procesal Penal peruano existen normas con rezagos inquisitivos que vienen siendo aplicadas de forma literal, impidiendo la consolidación del Modelo Acusatorio en el Perú. Tales rezagos inquisitivos afectan la consolidación de la oralidad y el sistema de audiencias, el sistema adversativo del juicio oral, así como el diseño de una investigación eficiente basada en la coordinación entre la Policía y Fiscalía. El problema se agrava, porque en el Perú no se hizo una reforma integral del sistema jurídico (Constitución y Leyes Orgánicas) que garantice el cambio real de la justicia penal, tal como se hizo en Chile y Colombia. Ante el defecto del legislador, surge la opción de realizar una interpretación constitucional de dichas normas -conforme lo estipula el artículo X del T.P. del NCPP- para garantizar el éxito de la reforma procesal penal en el Perú.
\end{abstract}

Palabras clave: Modelo acusatorio - Rezagos inquisitivos - Nuevas prácticas - Interpretación constitucional.

\begin{abstract}
In the text of New Criminal Procedure Code with lags Peruvian rules exist that are being applied inquisitive literally, impeding the consolidation of the Adversarial Model in Peru. Such lags inquisitive affect the consolidation of oral audiences system and the adversarial system of trial and the design of an efficient investigation based on coordination between the police and prosecution. The problem is aggravated because in Peru there was an integral reform of the legal system (Constitution and Organic Laws) to ensure real change in criminal justice, such as in Chile and Colombia. Before the defect of the legislature, there is the option of a constitutional interpretation of these rules, as stipulated in Article X of TP the NCPP, to ensure the success of the criminal procedure reform in Peru.
\end{abstract}

Key words: Model accusatory - Questioning lags - New practices, Constitutional interpretation.

\section{Sumario}

1. Introducción. 2. Rezagos inquisitivos en el Código Procesal Penal. 3. Apuntes para la interpretación constitucional de los rezagos inquisitivos del Código Procesal Penal. 4. Reforma procesal penal, principio de oralidad y Constitución. 5. La forma oral de las resoluciones judiciales forma parte de la garantía de motivación contenida en el arrtículo $139^{\circ}$ inciso 5 de la Constitución. 6. Conclusiones.

\footnotetext{
* Juez Superior Titular de la Corte Superior de Justicia de La Libertad-Poder Judicial del Perú. Profesor de la Academia de la Magistratura, Universidad Nacional de Trujillo y del Post Grado de la Universidad Nacional Pedro Ruiz Gallo.
} 
Víctor Burgos Mariños - Apuntes para la interpretación constitucional del Código Procesal Penal

\section{INTRODUCCIÓN}

En el Perú, a partir de la Constitución de 1979, el Ministerio Público se convierte en un organismo autónomo y en el titular del ejercicio de la acción penal (Cubas Villanueva, 2005:230), generando las bases del Modelo Acusatorio a través de la separación de funciones de persecución y jurisdicción penal. Sin embargo, pese a la promulgación de la Ley Orgánica del Ministerio Público (1981), el Código de Procedimientos Penales de 1939, mantenía vigente el modelo mixto inquisitivo, donde el Juez de Instrucción tenía la función de investigación del delito. E incluso, el 12 de junio de 1981 se promulga el Decreto Legislativo $\mathrm{N}^{\circ} 124$, que regula al proceso penal sumario, un proceso con características inquisitivas propias de la edad media, donde "se elimina el juicio oral y no se toma en cuenta el principio del juez no prevenido" (San Martín Castro, 2003:47), es decir, el mismo Juez que investigaba era el mismo que sentenciaba el caso, en un procedimiento escrito y no contradictorio. Pese a que la Constitución sentaba las bases del Modelo Acusatorio, el legislador, a través de la ley procesal (Decreto Legislativo $\mathrm{N}^{\circ} 124$ ), fortalecía la presencia del modelo inquisitivo.

Gracias a los esfuerzos de académicos y magistrados, se impulsó un nuevo intento de reforma, que culminó con la promulgación del Código Procesal Penal de 1991 de corte Acusatorio, mediante el Decreto Legislativo $N^{\circ}$ 638, publicado el 27 de abril de 1991, sin embargo el Modelo Procesal nunca entró en vigencia, pues el legislador lo dejó en vacatio legis, poniéndose en vigencia solo algunos artículos, el modelo imperante siguió siendo el Mixto Inquisitivo. Luego, mediante el Decreto Ley No 26147, publicada el 30 de diciembre de1992, se ratifica la vigencia del proceso penal sumario, al disponerse la adecuación de los delitos del Código Penal de 1991 al procedimiento regulado por el Decreto Legislativo $\mathrm{N}^{\circ} 124$. De esta manera, la reforma del sistema penal peruano operada el año 1991 (este año se promulgaron los Códigos Penal, Procesal Penal y de Ejecución Penal), fue sometida a la cultura inquisitiva del proceso penal sumario.

Con la promulgación de la Constitución de 1993, y la constitucionalización de la dirección fiscal de la investigación, el mismo que para muchos era ya un reconocimiento expreso del Modelo Acusatorio (de forma parcial, pero un gran paso), hacía inminente la entrada en vigencia del Código Procesal Penal de 1991, sin embargo ello nunca ocurrió, a pesar de los proyectos de 1995 y 1997, por supuestos "inconvenientes técnicos" (Oré Guardia, 1999:48). Para finalmente, con la puesta en vigencia de la Ley $\mathrm{N}^{\circ} 26689$, publicada el 30 de Noviembre de 1996, el proceso penal sumario (inquisitivo) pasa a 
Víctor Burgos Mariños - Apuntes para la interpretación constitucional del

Código Procesal Penal

consolidarse como la vía procesal hegemónica de la justicia penal en nuestro país, reservándose las normas del proceso penal ordinario (mixto inquisitivo) para un reducido grupo de delitos. Se advierte que pese a que la Constitución de 1993 había recogido un modelo acusatorio, a través de la dirección fiscal de la investigación, en la realidad se venían aplicando las reglas procesales del proceso sumario inquisitivo y del proceso ordinario mixto inquisitivo, lo que revela que la cultura jurídica predominante de los operadores de justicia, era el de preferir la aplicación literal de la ley procesal (inquisitivo), que lo previsto en la Constitución (acusatorio).

A partir del año 2000, hubo un nuevo intento de reforma, Oré Guardia (WEB, 2004) señala que "somos testigos del resurgimiento de un movimiento de reforma promovido en diferentes comisiones; las cuales han producido valiosos documentos. La Comisión del Poder Judicial ha elaborado el Informe de la Comisión de Bases para la Reforma del Proceso Penal; mientras que la Comisión de Alto Nivel del Ministerio de Justicia y el Proyecto Huanchaco han propuesto sus respectivos Anteproyectos de Código Procesal Penal", que con sus aportes, se promulga el Nuevo Código Procesal Penal también de corte acusatorio, mediante el Decreto Legislativo 957, publicado el 29 de julio de 2004, pero se observa que esta nueva propuesta legislativa, no había sido acompañada de las reformas legales y constitucionales que se necesitaban para garantizar su correcta implementación, tal como ocurrió en las experiencias de Chile y Colombia.

Si bien es cierto que el Nuevo Código Procesal Penal no entró en vigencia de inmediato, sino hasta después de 2 años, se debió en ese tiempo realizar las reformas de las Leyes Orgánicas del Poder Judicial, del Ministerio Público y de la Policía Nacional, y también, de la Constitución, para positivizar el Modelo Acusatorio en forma integral, y así facilitar su implementación, sin embargo, nada de esto sucedió.

Así, el 1 de julio de 2006, en el Distrito Judicial de Huaura, donde se inició su aplicación gradual en nuestro País. Siendo La Libertad el segundo Distrito Judicial que lo aplica a partir del 01 de abril de 2007, y a la fecha, si bien el Código Procesal Penal viene aplicándose a nivel nacional (al menos para los casos de corrupción de funcionarios), lo cierto es, que viene desarrollándose un duelo de prácticas, entre las viejas prácticas procesales inquisitivas y las nuevas prácticas procesales acusatorias (Binder, 2005:25). Este duelo de prácticas tiene que darse en un escenario donde existan las condiciones para sustituir las viejas prácticas procesales y administrativas, basadas en la escrituralidad y la cultura del expediente, por las nuevas prácticas basadas en la oralidad y el sistema de audiencias. 
Víctor Burgos Mariños - Apuntes para la interpretación constitucional del

Código Procesal Penal

Lamentablemente, no se han generado las condiciones para ese duelo de prácticas, pues, no se cuenta con el presupuesto adecuado, falta consenso de las instituciones, y en el ámbito jurídico, no se ha reformado la Constitución y las Leyes Orgánicas, y existen normas con rezagos inquisitivos en el Código Procesal Penal, cuya aplicación literal viene generando un conflicto de interpretaciones y de prácticas procesales, que ha puesto en grave riesgo el proceso de reforma de la justicia penal en el Perú, la cual se ha orientado hacia el modelo procesal acusatorio.

En efecto, según la Exposición de Motivos del Código Procesal Penal ${ }^{1}$, el legislador señala que "...la estructura del nuevo proceso penal así como sus instituciones allí contenidas se edifican sobre la base del modelo acusatorio de proceso penal cuyas grandes líneas rectoras son: separación de funciones de investigación y de juzgamiento; el Juez no procede de oficio; el Juez no puede condenar ni a persona distinta de la acusada, ni por hechos distintos de los imputados; el proceso se desarrolla conforme a los principios de contradicción e igualdad; la garantía de la oralidad es la esencia misma del juzgamiento y; la libertad del imputado es la regla durante todo el proceso. Es de destacar como una nota trascendental la implantación de la oralidad en la medida que permite que los juicios se realicen con inmediación y publicidad, permitiendo de esa forma un mayor acercamiento y control de la sociedad hacia los encargados de impartir justicia en su nombre".

El hecho que esté vigente el Modelo Acusatorio en el Perú, no significa que realmente estemos "viviendo" (trabajando) conforme al Modelo Acusatorio. Según Aguiló (2008:84) una cosa es tener una Constitución y otra es vivir en Constitución, "...una buena concepción de la Constitución tiene que ser capaz de integrar el sentido de darse una constitución con el de vivir en constitución", para ello tiene que consolidarse una práctica constitucional orientada por principios y valores. Para reformar la justicia, no basta el haberse dado un nuevo modelo procesal de corte acusatorio, nos falta vivir (trabajar) como en un modelo acusatorio, para ello se hace necesario desarrollar una práctica procesal orientada hacia los valores y principios del modelo acusatorio.

En Chile, a partir de la Ley de reforma constitucional $N^{\circ} 19.519$, publicada el 16 de septiembre de 1997, que coincidentemente creo al Ministerio

\footnotetext{
1 La Comisión de Alto Nivel del Ministerio de Justicia, al concluir la redacción del Nuevo Código Procesal Penal de 2004, elevó un Anteproyecto, el que tenía la exposición de motivos. Sin embargo, al promulgarse el texto legal, se omitió incluir la Exposición de Motivos. Tal omisión, sin duda, no impide conocer la voluntad o intención del Legislador, y en la cita se aprecia con claridad, que el modelo que se adopta, es el acusatorio de proceso penal, y con predominio de la oralidad. Ver el siguiente enlace: http://www.unifr.ch/ddp1/ derechopenal/legislacion/1_20080616_80.pdf.
} 
Víctor Burgos Mariños - Apuntes para la interpretación constitucional del

Código Procesal Penal

Público como un organismo autónomo y jerarquizado que tiene a cargo la investigación penal, el ejercicio de la acción penal pública, y la adopción de medidas para proteger a víctimas y testigos, se dieron una serie de reformas para crear las condiciones para la implementación de un modelo procesal penal de corte acusatorio. Así por ejemplo, la Ley Orgánica Constitucional del Ministerio Público (Ley No 19.649, de 15 de octubre de 1999); el Código Procesal Penal (Ley $N^{\circ} 19.696$, de 12 de octubre de 2000); la Leyes $N^{\circ} 19.665$, de 9 de marzo de 2000 y N 19.708, de 5 de enero de 2001, que modifican el Código Orgánico de Tribunales; la Ley N 19.718, de 10 de marzo de 2001, que crea la Defensoría Penal Pública (Horvitz Lennon, 2005: 23).

La reforma chilena responde, en general, a un sistema acusatorio, siendo su principal expresión legislativa, el nuevo Código Procesal Penal, que establece la introducción de un juicio oral ante un panel de tres jueces como forma central de juzgamiento, suprime la figura del juez de instrucción y entrega la tarea de preparación del juicio al Ministerio Público, supervisado por un juez especialmente creado para cumplir esa tarea, llamado Juez de Garantía. Al mismo tiempo, el nuevo Código entregó a los fiscales del Ministerio Público diversas facultades destinadas a permitirles utilizar procedimientos alternativos al tradicional, con el fin de dar lugar a soluciones negociadas y descongestionar el sistema judicial del excesivo número de casos que habitualmente se le presentan. Una característica llamativa del proceso de reforma en Chile fue la creación de entidades completamente nuevas para hacerse cargo tanto de la función de persecución como de la defensa pública. Asimismo, los tribunales fueron objeto de importantes reformas orgánicas que abarcaron tanto las funciones jurisdiccionales, al crearse dos nuevas categorías de jueces, como las de administración, donde se estableció todo un nuevo sistema de gestión, por el cual se suprimió el despacho tradicional y se reemplazó por despachos colectivos, que abarcan a todos los jueces de una categoría dentro de cada ciudad, y cuya administración se entrega a un equipo profesional especializado. En términos generales, el proceso de reforma ocurrido en Chile tiene como característica ser un proceso bastante sistemático, gradual y bien financiado. Esto es, todas las instituciones han comenzado a conocer los casos bajo el nuevo sistema de acuerdo con una planificación bastante detallada de los procesos de instalación de tribunales, fiscales y defensores, de la ejecución de programas de capacitación para todos ellos, y de la disposición de infraestructura para el desarrollo de las nuevas funciones, en algunos casos nueva y en otros, acondicionada especialmente (CEJA, Proyecto de seguimiento de los procesos de reforma judicial en América Latina: Chile, 2005). 
Víctor Burgos Mariños - Apuntes para la interpretación constitucional del

Código Procesal Penal

En Colombia, a fines de la década de los 90s, se dictó un Nuevo Código de Procedimiento Penal a través de la Ley 600, pero durante su difusión, sectores de la academia y la sociedad civil insistieron en la necesidad de reformar integralmente el proceso penal hacia un sistema acusatorio oral, con un juicio público, contradictorio y concentrado. Sin embargo, la ley 600 mantuvo las características del Modelo Mixto, manteniendo así, la estructura básica del proceso penal conforme a la Constitución de 1991. En consecuencia, la ley no podría introducir un sistema de corte acusatorio, sin previa reforma constitucional (CEJA, Informe de seguimiento de la Reforma Procesal Penal en Colombia, 2006). Por ello la Fiscalía presentó una iniciativa de reforma constitucional al Congreso. Con base en ella, se expidió el acto legislativo 03 de 2002, que introdujo las reformas básicas al texto constitucional, diseñó una implementación gradual y conformó una Comisión que debía producir un código en esta materia y vigilar la implementación del sistema. La citada comisión presentó al Congreso un proyecto de Código de Procedimiento Penal, que luego de algunas modificaciones culminó con la promulgación de la ley 906 de 2004.

Las principales características del sistema acusatorio colombiano son: el método de trabajo del sistema es oral, a través de audiencias, y el expediente se reduce a una carpeta informal de recaudo de información para el registro interno de la fiscalía; se introdujo el principio de oportunidad, como un mecanismo para que la fiscalía racionalice el ejercicio de la acción penal, de acuerdo con la política criminal; se creó la figura del juez de control de garantías, quien debe tomar las decisiones que afecten derechos fundamentales del imputado durante la investigación (salvo en materia de restricciones al derecho a la intimidad, en que el control del juez de garantía es posterior, dentro de las 36 horas siguientes; se entregó a la víctima un catálogo de derechos, en el entendido que su rol en el proceso penal no debe reducirse al reclamo de una indemnización, sino que tiene derecho a conocer la verdad y reclamar que se haga justicia. Las decisiones que ponen fin al proceso penal deben tener control judicial, para posibilitar la intervención de la víctima en contra de esta decisión; se introdujo la suspensión del procedimiento a prueba, que permite que frente a ciertos delitos, el imputado presente un plan de reparación del daño y se suspenda el ejercicio de la acción penal por un término, bajo el cumplimiento de ciertas condiciones; se regularon otras formas de terminación del proceso penal con imposición de condena, fuera del juicio oral. Nos referimos a los preacuerdos de pena como forma negociada de poner fin al proceso y la aceptación de cargos, como aceptación anticipada de responsabilidad penal del imputado, con rebaja de pena; se introdujo el juicio oral como fase central del procedimiento, que debe desarrollarse de 
Víctor Burgos Mariños - Apuntes para la interpretación constitucional del

Código Procesal Penal

forma oral, pública, contradictoria, con inmediación y concentración; y se introdujo el incidente de reparación integral, en el cual una vez declarada la responsabilidad del acusado, la víctima pone en práctica la reclamación de una pretensión económica u otro tipo de reparación.

Así, la reforma procesal penal en Colombia, se encuentra en estado propicio para dotar a la administración de justicia penal, de un sistema ágil que permita combatir eficazmente el delito sin sacrificar la opción positiva de la Constitución a favor de los derechos humanos; que el modelo acusatorio no solo favorece al respeto de las garantías constitucionales, sino también dota de instrumentos a nuestra jurisdicción para alcanzar una mayor eficiencia en la persecución del crimen. Igualmente, es un imperativo para evitar el atraso científico (Gonzáles Navarro, 2005:59).

Como se podrá observar de las dos experiencias de reforma procesal penal más exitosas en América Latina, como lo son Chile y Colombia, se tuvo que reformar la Constitución y las leyes orgánicas, para garantizar una correcta implementación del Modelo Acusatorio, lo que no ha ocurrido en el Perú. Digamos, que en Chile y Colombia, están viviendo (trabajando) conforme al modelo acusatorio.

En el Perú, a pesar de los 5 años de reforma, aún no se ha consolidado una práctica procesal uniforme y afín al modelo acusatorio, podríamos señalar que existen dos prácticas, una derivada de la aplicación literal de las normas inquisitivas que tiende a mantener el viejo modelo mixto inquisitivo, es decir una práctica inquisitiva, y otra, derivada de la interpretación constitucional de dichas normas, practicas acusatorias, que se basan en la aplicación de los métodos de "ponderación y el comparativo, con independencia de otros métodos aplicables a instituciones constitucionales...como la de los derechos fundamentales" (Ferrer Mac-Gregor, 2005:XIX), haciendo prevalecer la Constitución y los principios del Modelo Acusatorio a los normas inquisitivas. En suma, a pesar de habernos dado un modelo acusatorio, aún no vivimos (trabajamos) en modelo acusatorio, pues hay quienes viven (trabajan) como en el modelo mixto inquisitivo; pero también hay quienes viven (trabajan) como en modelo acusatorio. Creo que es a nosotros, que nos corresponde elegir como queremos vivir y trabajar.

\section{REZAGOS INQUISITIVOS EN EL CÓDIGO PROCESAL PENAL}

Como es incuestionable, el código procesal penal de 2004 se adscribe a un sistema acusatorio contradictorio (Neyra Flores, 2010:111), sin embargo, el legislador al redactar el textolegal, no pudoevitar la presencia deinconsistencias 
Víctor Burgos Mariños - Apuntes para la interpretación constitucional del Código Procesal Penal

normativas, como la existencia de normas con rezagos inquisitivos. Parece que el legislador fue consiente de dicho riesgo, por ello sabiamente previó el artículo X del Título Preliminar, que establece que "Las normas que integran el presente Título prevalecen sobre cualquier otra disposición de este Código. Serán utilizadas como fundamento de interpretación". De tal manera, que se puede preservar la coherencia normativa del código procesal penal, si frente a una inconsistencia, se aplican los principios del modelo acusatorio. Caso contrario, si no se aplican dichos principios, y se realiza una aplicación literal, se daría una práctica procesal inquisitiva, incoherente con la necesidad de instalar las nuevas prácticas de carácter acusatoria.

La existencia de normas con rezagos inquisitivos en un Código Procesal de modelo acusatorio genera una inconsistencia de tipo normativa, mientras que la aplicación literal de dichas normas genera incoherencia en la práctica del proceso penal. En efecto, hay lugares donde se vive la práctica del proceso acusatorio-oral, pero hay otros donde se vive la práctica del proceso inquisitivo-escrito, lo que viene impidiendo la consolidación del nuevo proceso penal basado en la oralidad y el sistema de audiencias.

A continuación vamos a hacer una descripción de los principales problemas generados por la interpretación literal de las normas del Código Procesal Penal, y sus efectos en la práctica procesal, para advertir en algunos casos, lo riesgoso que puede ser generar y mantener prácticas incoherentes con el modelo acusatorio.

Veamos en primer lugar las normas relativas a la dirección de la investigación del delito. En el Código se citan las siguientes normas: el Artículo IV inciso 1 del Título Preliminar: "El Ministerio Público es titular del ejercicio público de la acción penal en los delitos y tiene el deber de la carga de la prueba. Asume la conducción de la investigación desde su inicio", el Artículo $60^{\circ}$ inciso 2: "El Fiscal conduce desde su inicio la investigación del delito. Con tal propósito la Policía Nacional está obligada a cumplir los mandatos del Ministerio Público en el ámbito de su función", el Artículo 65 inciso 3: "Cuando el Fiscal ordene la intervención policial, entre otras indicaciones, precisará su objeto y de ser el caso, las formalidades especificas que deberán reunir los actos de investigación para garantizar su validez. La función de investigación de la Policía Nacional estará sujeta a la conducción del Fiscal", y el Artículo 650 inciso 4: "Corresponde al Fiscal decidir la estrategia de investigación adecuada al caso...".

Ciertamente la relación del Ministerio Público y la Policía no fueron buenas, incluso desde antes de la entrada en vigencia del CPP, por muchas razones 
que no corresponden explicar ahora. Lo cierto es que la Policía siempre se ha opuesto a un modelo de investigación dirigida por el Ministerio Público. A partir de la interpretación literal de estas normas, se ha llegado a situaciones absurdas como afirmar "que quien dirige la investigación es el Ministerio Público, y por tanto la Policía no puede realizar ningún acto de investigación sin su autorización y dirección" "que la Policía no puede hacer nada hasta que llegue el Fiscal". Esta forma de interpretación hizo que se confundiera "dirección de investigación" por "control de la actuación policial", por lo que más esfuerzos se despliegan para el control, que para la dirección. De otro lado, la Policía ha reaccionado a modo de protesta, "no haciendo nada hasta que el Fiscal lo disponga", generando una significativa disminución de sus intervenciones y protestando en espacios públicos, que "el Nuevo Código Procesal Penal les ha recortado sus funciones y ya no pueden investigar o intervenir como antes". Entonces, la aplicación literal de las normas citadas, no ha fortalecido el desarrollo de una investigación eficiente, basada en una mayor capacidad operativa, labor de inteligencia y coordinación entre el Ministerio Público y la Policía Nacional.

Respecto a la facultad de la Policía de calificar jurídicamente los hechos, el Código establece en el Artículo $332^{\circ}$ inciso 2 que "El Informe Policial contendrá los antecedentes que motivaron su intervención, la relación de las diligencias efectuadas y el análisis de los hechos investigados, absteniéndose de calificarlos jurídicamente y de imputar responsabilidades". En una aplicación literal de esta norma, se ha llegado a prohibir a los miembros de la Policía hacer toda referencia del delito motivo de la investigación, incluso en las comunicaciones que cursa a la Fiscalía o a otras dependencias, como medicina legal, criminalística, etc. Esto ha generado un detrimento en las capacidades investigativas de la Policía, pues el Código no le quita facultades investigativas, sino que por el contrario lo potencia, con una mayor capacidad operativa, sin embargo, mediante interpretaciones literales como ésta, se les limita ostensiblemente. Para hacer una buena investigación se tiene que manejar información sobre la calificación jurídica del hecho, desde los primeros momentos de la intervención policial, para realizar no solo los actos de investigación urgentes, sino también para la actuación de prueba técnica pericial, pues se tiene que saber que elementos del delito deben acreditarse. En efecto, la calificación inicial del hecho es útil como criterio orientador de la investigación. La prohibición a la Policía de no calificar el hecho, es para el final de la investigación preliminar, como conclusión de responsabilidad, y no para realizar la investigación. Si se prohíbe a la Policía que califique el hecho al inicio o durante la investigación, ésta quedará totalmente desorientada e ineficaz, produciendo además, un debilitamiento de las funciones de investigación de la Policía. 
Víctor Burgos Mariños - Apuntes para la interpretación constitucional del Código Procesal Penal

Una norma que consideramos como rezago inquisitivo es la prevista en el artículo $268^{\circ}$, inciso 1 " $\mathrm{b}$ ", que establece como requisito sustancial para la prisión preventiva "Que, la sanción a imponerse sea superior a cuatro años de pena privativa de libertad". En el modelo inquisitivo la prisión preventiva era usada como pena anticipada, por ello se ordenaba la prisión con la finalidad de asegurar la futura condena. Como se podrá observar, al imponer la prisión con esa única finalidad, se desnaturaliza su finalidad cautelar, y la presunción de inocencia es sustituida por la presunción de culpabilidad. En nuestro sistema penal, si se impone una pena mayor de 4 años, la pena será efectiva y se ejecutará de inmediato, aun cuando se interponga recurso de apelación. Por ello si el Juez decide imponer la prisión preventiva porque la pena a imponer al procesado será efectiva, entonces la medida cautelar se convierte en pena anticipada y se viola el principio de presunción de inocencia. En muchos casos de la práctica, cuando la Fiscalía no tiene elementos de convicción para acreditar el peligro procesal, o cuando tiene casos por delitos graves, suelen emplear el argumento de la gravedad del delito y la pena, para fundamentar el requerimiento de prisión preventiva. En suma, si se genera una práctica de la prisión preventiva sustentada en asegurar la futura condena, se mantendrá la cultura inquisitiva de la prisión preventiva como pena anticipada; en cambio, si se sustenta en la peligrosidad procesal, se generará la práctica de la prisión preventiva como medida cautelar respetuosa de la presunción de inocencia.

Otra interpretación literal, hasta cierto punto intencionadamente contrareformista, se hizo respecto del Artículo I del Título Preliminar, inciso 2, "Toda persona tiene derecho a un juicio previo, oral, público y contradictorio". En esta línea interpretativa se llega a considerar que los principios de oralidad, publicidad y contradicción solo deben ser aplicables al Juicio Oral, pues solo se prevé expresamente para el juicio oral y no para la etapa de investigación preparatoria. En consecuencia, las audiencias previas al juicio deben ser realizadas sin oralidad, publicidad ni contradicción. Por suerte, esta interpretación solo tuvo una vigencia pasajera en algunos Distritos judiciales, como algunos recordarán, pues al final se impuso la fuerza de la oralidad. Este tipo de interpretación, parece absurda, pero increíblemente se ha dado.

El artículo $135^{\circ}$ inciso 1 , es una norma que contiene rezago inquisitivo, pues su interpretación literal promueve la formación de expedientes y afecta la oralidad y el Nuevo Despacho Judicial del Modelo Acusatorio. En efecto, pues según su texto, el Código establece que "Los requerimientos que el Fiscal formula al Juez de la Investigación Preparatoria deben acompañarse con el expediente original o con las copias certificadas correspondientes...". Basta imaginar, cuantos requerimientos puede solicitar el MP en esta etapa, para 
Víctor Burgos Mariños - Apuntes para la interpretación constitucional del

Código Procesal Penal

inferir -de acuerdo a una interpretación literal- las veces que se va a copiar la carpeta fiscal. Las repetidas copias de la carpeta fiscal son contradictorias al sistema oral, pues lo central ahora es la audiencia y porque no tiene sentido lógico ni práctico, tener varias veces la misma copia. Los Distritos Judiciales donde hacen una interpretación literal de esta norma, centran su mayor preocupación en la gestión de expedientes, pero afrontan el problema de tener expedientes más voluminosos que en el modelo anterior, la falta de personal, la falta de ambientes para almacenar los expedientes y de tenerse que quedar horas extras para tenerlos al día. Sin duda que esta norma es un rezago inquisitivo, que mantiene las viejas prácticas e impide la consolidación del modelo acusatorio.

Otra norma cuya interpretación literal afecta al modelo acusatorio es la prevista en el artículo $468^{\circ}$ inciso 1, el que impide la aplicación del proceso especial de terminación anticipada durante la etapa intermedia, pues no propicia las salidas alternativas y tener al juicio oral como una etapa principal y excepcional. También afecta al derecho del imputado a una pena más justa y a la disponibilidad que tiene sobre su derecho al juicio oral. Según su texto se prevé que: "A iniciativa del Fiscal o del imputado, el Juez de la Investigación Preparatoria dispondrá, una vez expedida la Disposición Fiscal del artículo $336^{\circ}$ y hasta antes de formularse acusación fiscal, pero por una sola vez, la celebración de una audiencia de terminación anticipada, de carácter privada. Su celebración no impide la continuación del proceso. Se formará, al respecto, cuaderno aparte". Esta norma además es discriminatoria y desconoce la naturaleza de salida alternativa al juicio oral que tiene la terminación anticipada, al igual que el principio de oportunidad, con la diferencia que éste si está autorizada su aplicación en la etapa intermedia de forma expresa. Se fomenta la producción de juicios que ocupan la atención de todo el sistema, cuando bien pudieron resolverse alternativamente.

El artículo $370^{\circ}$ inciso 1, sobre la Ubicación de las partes en el juicio oral, es sin duda, un rezago inquisitivo, pues veamos, según su texto establece que: "El Juez Penal tendrá a su frente al acusado; a su derecha, al Fiscal y al abogado de la parte civil; y, a su izquierda al abogado defensor del acusado". Según esta norma, el acusado mantiene la misma ubicación en el Juicio Oral del modelo Mixto inquisitivo, donde el acusado era ubicado, solo y al centro en el banquillo de los acusados, en su condición de objeto de prueba. Esta ubicación impide a la Defensa del imputado tener igualdad procesal, promueve que el interrogatorio del acusado siga siendo lo más importante del juicio oral e impide la consolidación del Modelo Acusatorio a través del debate contradictorio, la teoría del caso y las técnicas de litigación oral. 
Víctor Burgos Mariños - Apuntes para la interpretación constitucional del Código Procesal Penal

Los artículos $371^{\circ}, 372^{\circ}$ y $373^{\circ}$, tienen como característica el de mantener el orden preclusivo del juicio oral del modelo mixto inquisitivo, así se desprende del texto literal del Artículo $371^{\circ}$ inciso 2: "Acto seguido, el Fiscal expondrá resumidamente los hechos objeto de la acusación, la calificación jurídica y las pruebas que ofreció y fueron admitidas. Posteriormente, en su orden, los abogados del actor civil y del tercero civil expondrán concisamente sus pretensiones y las pruebas ofrecidas y admitidas. Finalmente, el defensor del acusado expondrá brevemente sus argumentos de defensa y las pruebas de descargo ofrecidas y admitidas" (luego de instalada la audiencia, se sigue con los alegatos de apertura donde las partes presentan su teoría del caso); El Artículo $372^{\circ}$ inciso 1: "El Juez, después de haber instruido de sus derechos al acusado, le preguntará si admite ser autor o partícipe del delito materia de acusación y responsable de la reparación civil" (luego de los alegatos de apertura, luego de haber escuchado las teorías del caso, se da inicio al proceso de conformidad); y, el Artículo $373^{\circ}$ inciso 1 y 2: "Culminado el trámite anterior, si se dispone la continuación del juicio, las partes pueden ofrecer nuevos medios de prueba..."; "Excepcionalmente, las partes podrán reiterar el ofrecimiento de medios de prueba inadmitidos en la audiencia de control, para lo cual se requiere especial argumentación de las partes...", (luego de la presentación de las teorías del caso de las partes, se da inicio a un debate para la admisión de nuevas pruebas, que por lo general toma su tiempo y afecta la continuidad del juicio). La aplicación literal de estas normas tienden a mantener el mismo orden del juicio oral del modelo anterior; debilita la credibilidad de la teoría del caso de la Defensa; luego de la tesis de defensa se le pregunta al acusado si se declara culpable (conformidad); se mantiene así, el prejuicio de la presunción de culpabilidad propio del inquisitivo; debilita la inmediación del Juez entre la teoría del caso planteado por las partes y el debate probatorio; se admite nueva prueba y no se modifican las teorías del caso; se impide el desarrollo y consolidación de los principios y valores del Modelo Acusatorio y las técnicas de litigación oral.

El artículo $375^{\circ}$ inciso 1, es también un rezago inquisitivo pues mantiene al interrogatorio del acusado, como la primera y más importante actuación probatoria del juicio oral, así parece desprenderse de su texto: "El debate probatorio seguirá el siguiente orden: a) Examen del acusado; b) Actuación de los medios de prueba admitidos; c) Oralización de los medios probatorios". Esta norma mantiene la cultura y la práctica de tratar al acusado como objeto de prueba, afectando su derecho de defensa; se le obliga a declarar antes del debate probatorio, cuando lo más favorable para la defensa es declarar al final para poder cuestionar la prueba de cargo; afecta las reglas del debate contradictorio o adversarial; al Fiscal se le obliga a demostrar su teoría del caso con la declaración del acusado, no con sus pruebas más importantes; el Fiscal 
Víctor Burgos Mariños - Apuntes para la interpretación constitucional del

Código Procesal Penal

mantiene el mismo interrogatorio del viejo modelo, impidiendo el desarrollo de las reglas del examen directo y el contraexamen; atenta contra el desarrollo de las técnicas de litigación oral y del modelo acusatorio adversarial. Esta norma cuando se aplica literalmente, trae como efecto, que se mantenga la práctica inquisitiva del juicio oral del modelo mixto inquisitivo, donde la declaración del imputado era la prueba por excelencia.

En el mismo sentido, la aplicación literal del artículo 378 inciso 4 que prescribe que "El Juez moderará el interrogatorio y evitará que el declarante conteste preguntas capciosas, sugestivas o impertinentes..." fomenta que los jueces mantengan una participación protagónica e intervencionista del debate probatorio, impidiendo el desarrollo de las técnicas de litigación oral. En efecto, la aplicación literal genera que los jueces actúen de oficio durante los interrogatorios para controlar las preguntas, cuando ello en un sistema acusatorio es potestad de las partes. Asimismo, la aplicación literal de este artículo que prohíbe las preguntas sugestivas, viene impidiendo el desarrollo del contraexamen como técnica de litigación oral, ya que el uso de preguntas sugestivas da eficacia al control de la prueba personal.

La aplicación literal del artículo $9^{\circ}$ inciso 2, fomenta la permanencia del expediente en los recursos impugnatorios, debilitando la oralidad y el nuevo despacho judicial basado en el sistema de audiencias. El texto legal es el siguiente: "Concedido el recurso de apelación, el Juez de la Investigación Preparatoria dispondrá, antes de la elevación del recurso a la Sala Penal Superior, que dentro del quinto día se agreguen a los actuados formados en sede judicial las copias certificadas pertinentes del expediente fiscal. Si transcurre el plazo sin que se haya agregado las copias correspondientes, el Juez inmediatamente elevará los actuados a la Sala Penal Superior, la que sin perjuicio de poner este hecho en conocimiento del Fiscal Superior instará al Fiscal Provincial para que complete el cuaderno de apelación.". Esta norma, conjuntamente con la prevista en el artículo 135 inciso 1 , son las que vienen generando y manteniendo la práctica de sacar copia del expediente fiscal, cada vez que se realice un requerimiento o apelación, con lo que prácticamente en la actualidad, donde se aplica literalmente estas normas inquisitivas, se está dando más importancia al expediente que a la audiencia, y se están produciendo expedientes más voluminosos, incluso, que en el modelo inquisitivo.

El artículo $420^{\circ}$ inciso 5 también constituye un rezago inquisitivo, pues configura a la audiencia de apelación de autos, como si fuera una vista de la causa del anterior modelo inquisitivo. Así se desprende de su texto que prevé "A la audiencia de apelación podrán concurrir los sujetos procesales 
Víctor Burgos Mariños - Apuntes para la interpretación constitucional del

Código Procesal Penal

que lo estimen conveniente. En la audiencia, que no podrá aplazarse por ninguna circunstancia, se dará cuenta de la resolución recurrida, de los fundamentos del recurso y, acto seguido, se oirá al abogado del recurrente y a los demás abogados de las partes asistentes. El acusado, en todo caso, tendrá derecho a la última palabra". La interpretación literal de esta norma está generando una desnaturalización de la audiencia y una práctica perjudicial para el nuevo Modelo Acusatorio, pues la audiencia de apelación de autos se viene realizando con una sola de las partes, o incluso, sin partes. Esta norma y las prácticas derivadas de su interpretación literal son incoherentes y contradictorias a las reglas de la apelación y la casación previstas en el Código Procesal Penal, donde se exige la concurrencia de la parte apelante y se garantiza el debate contradictorio. En efecto, en un sistema oral, la audiencia tiene que desarrollarse bajo la regla de la contradicción, y para ello deben asistir las partes contrarias, sin embargo de la lectura literal que hacen algunos operadores, entienden que a la audiencia pueden asistir las partes que lo deseen, lo que ha promovido como mala práctica que la audiencia de apelación de autos se realice con una parte o sin partes, y que la audiencia sea vista como algo simbólico y formal, al que nadie tiene interés de asistir. Además, su lectura literal lleva a entender que la parte apelante no tiene la obligación de concurrir a la audiencia, lo que es incoherente y contradictorio con la regla del deber de concurrir del recurrente, prevista tanto para la apelación de sentencias y la casación de autos y sentencias, lo que promueve el uso de recursos inoficiosos, dilatorios y maliciosos, que la Sala se ve en la obligación de resolver con la lectura del expediente.

La aplicación literal del artículo $423^{\circ}$ inciso 3, puede generar una grave afectación al derecho de defensa, veamos sino, según el texto legal se señala que "Si el acusado recurrente no concurre injustificadamente a la audiencia, se declarará la inadmisibilidad del recurso que interpuso. De igual manera se procederá si no concurre el Fiscal cuando es parte recurrente". ¿Qué pasa entonces si a la audiencia de apelación de la sentencia condenatoria no asiste el acusado de forma injustificada, pero si su abogado defensor? ¿Se declara o no inadmisible el recurso? ¿Qué pasa en un caso de pluralidad de imputados apelantes de una sentencia condenatoria, cuando algunos acusados no asisten, pero si sus abogados, también se declara inadmisible los recursos de los inconcurrentes? $Y$, ¿qué pasa si en este último caso, la sentencia es revocada por que no hay delito ni responsabilidad penal?, ¿cómo queda la sentencia firme por efecto de la inadmisibilidad del recurso? Como se podrá advertir, la aplicación literal de esta norma, viene generando la afectación del derecho a la doble instancia del imputado condenado, pese a concurrir a la audiencia de apelación su abogado defensor. 
Si hacemos una evaluación de la aplicación literal de estas normas, vamos a darnos cuenta que la forma como se viene trabajando, no es como en un modelo acusatorio, sino como en el modelo mixto inquisitivo. En efecto, aun no se desarrolla una investigación eficiente producto del trabajo conjunto entre el Ministerio Público y la Policía Nacional, no se ha consolidado la audiencia ya que el expediente sigue siendo muy importante, a tal punto que ahora son más voluminosos, el juicio oral sigue el mismo trámite que en el modelo mixto inquisitivo, con el acusado al centro y con su interrogatorio como la más importante actuación probatoria (objeto de prueba), los jueces no resuelven oralmente, sino por escrito y notifican la resolución, se mantiene la delegación y reaparece la carga procesal. Estas prácticas mantienen al viejo modelo, así como sus problemas estructurales, lo que indica que la reforma procesal penal es ineficaz. Todo ello viene impidiendo que las nuevas prácticas se instalen y se desarrollen para materializar la reforma procesal penal, de continuar y generalizarse, la implementación del modelo acusatorio en el Perú, corre grave riesgo de frustrarse.

\section{APUNTES PARA LA INTERPRETACIÓN CONSTITUCIONAL DE LOS REZAGOS INQUISITIVOS DEL CÓDIGO PROCESAL PENAL}

El Estado eligió como oferta de cambio de la justicia penal, la sustitución del modelo mixto inquisitivo por el modelo acusatorio, así se desprende de los proyectos de 1990, el Código Procesal Penal de 1991, los Proyectos de 1995 y 1997, el Proyecto Huanchaco, el Anteproyecto de la Comisión de Alto Nivel y el Código Procesal Penal, ambos del año 2004. Entonces es evidente que todos los ciudadanos, me incluyo, esperamos que la aplicación del Código Procesal Penal y el Modelo Acusatorio produzca un cambio real en la administración de justicia penal.

En efecto, la vigencia y aplicación del Modelo Acusatorio es una exigencia de la sociedad peruana, y a la vez del deber del Estado frente a la oferta pública señalada en la opción por el Modelo Acusatorio contenido en el Nuevo Código Procesal Penal. También responde a una exigencia de la Constitución y la legislación supranacional sobre derechos humanos, porque el modelo acusatorio es el que mejor responde y cautela los principios del debido proceso penal.

No hay duda que la opción del legislador del Código Procesal Penal del 2004 es por un modelo acusatorio ("relativo", "con rasgos adversariales", "moderado", "con tendencia...", etc.), que indistintamente como se le quiera llamar (según gustos o colores), debe garantizar la oferta de reformar (cambiar) 
Víctor Burgos Mariños - Apuntes para la interpretación constitucional del Código Procesal Penal

la justicia penal en el Perú. Esto quiere decir, que se deben dar las condiciones para generar las prácticas para poder "vivir y trabajar" como en un modelo acusatorio, y para lograr mínimamente aquello, se tiene que dejar de "vivir y trabajar" como en un modelo mixto inquisitivo.

El modelo acusatorio es hoy una demanda de la sociedad, es la oferta del Estado para cambiar la justicia, y es el modelo que mejor responde a las exigencias constitucionales del debido proceso. Es una aspiración social, una política pública y un valor constitucional. La sociedad necesita y demanda un modelo acusatorio, el Estado debe reformar la justicia penal a través del modelo acusatorio, porque el modelo acusatorio es un valor constitucional.

El modelo acusatorio, en todos lados, tiene principios y valores que lo caracterizan, y lo diferencian del modelo mixto inquisitivo. Tomaremos solo dos de ellos, la separación de roles y el sistema de audiencias (predominio de la oralidad), y así podremos afirmar, que en la medida que la separación de roles permita el desarrollo de la práctica adversarial o contradictoria de las partes, mediante la cual deberán buscar y defender su verdad, y llevar sus pruebas al Juez, empezaremos a "vivir y trabajar" como en un modelo acusatorio; de la misma manera, en la medida que el sistema de audiencias permita al Juez y a las partes trabajar públicamente, llevando su verdad a la audiencia, empezaremos a "vivir y trabajar" como en un modelo acusatorio. Esto es en definitiva, necesariamente diferente que en el modelo mixto inquisitivo.

Otra característica que podemos afirmar tiene el modelo acusatorio peruano, es el de ser eficiente y garantista, a diferencia del Modelo Acusatorio Chileno que propuso el modelo garantista (Maier, 2000: 179) y a diferencia del Modelo Acusatorio Colombiano que propuso el modelo eficiente (Maier, 2000: 243). Así se desprende de la Exposición de Motivos del Código Procesal Penal (Anteproyecto) “...el Código Procesal Penal que se propone constituye un instrumento normativo cuyo fin último es lograr el equilibrio de dos valores trascendentes: seguridad ciudadana y garantía. Es decir, por un lado dotar al Estado de las herramientas necesarias para que cumpla con su obligación de llevar adelante un proceso rápido y eficaz, que conlleve a la dación de una sentencia que redefina el conflicto generado por el delito satisfaciendo las legítimas expectativas de sanción y resarcimiento y, de otro lado, que la imposición de una sentencia se efectúe con irrestricta observancia de las garantías que establecen los Tratados Internacionales de Derechos Humanos que norman un procedimiento penal en un Estado democrático". 
Víctor Burgos Mariños - Apuntes para la interpretación constitucional del

Código Procesal Penal

El modelo acusatorio peruano en suma, para efecto del presente análisis, lo podríamos caracterizar, como un proceso de partes, fundamentalmente contradictorio y con un Juez imparcial (separación de roles), que trabajan públicamente en las audiencias (predominio de la oralidad), con eficiencia y respeto a las garantías del debido proceso. Esta caracterización nos puede permitir comprobar y medir si estamos o no trabajando como en un modelo acusatorio, sobre todo en la aplicación literal de las normas y de aquellas que mantienen rezagos inquisitivos.

En el Nuevo Código Procesal Penal no existe una etapa policial de investigación autónoma, y tampoco una etapa de investigación donde la Fiscalía la realice por su cuenta y con exclusión de la Policía. Por el contrario, en el Modelo Acusatorio, ya en aplicación progresiva en el país, se produce un cambio radical (cualitativo) e inexorable: quien asume la potestad constitucional de Dirigir la Investigación es el Fiscal, como titular que es del ejerció público de la acción penal (Constitución de 1993, Art. 159. 5: "Ejercer la acción penal de oficio o a petición de parte"). Por lo tanto, resultan excluidas tanto la idea como la práctica de "dirección policial paralela" o "investigación policial autárquica o autónoma" (Mixán Mass, 2008). Lo que el Nuevo Código Procesal Penal diseña es una etapa de investigación única, basada en el trabajo coordinado entre la Policía y el Ministerio Público, conforme lo estipula el artículo Art. $333^{\circ}$ del Código, es obligatorio que “...la Policía Nacional instituya un órgano especializado encargado de coordinar las funciones de investigación ... con el Ministerio Público..." para que en base a la información sobre la criminalidad violenta y organizada, se elabore programas y acciones para la adecuada persecución del delito, y programas de protección y seguridad. Para garantizar una investigación eficiente, no se deben realizar interpretaciones literales, en el sentido que es el Fiscal el único que puede dirigir la investigación, o es solo la Policía, sino que lo que se pretende es un trabajo coordinado. El Nuevo Código Procesal Penal otorga a la Policía una mayor capacidad operativa investigativa, lo que permite al Ministerio Público tener una buena investigación, y un buen juicio oral que garantice la sanción de los delitos.

La prisión preventiva no tiene por finalidad asegurar la futura condena, sino asegurar la presencia del imputado al juicio oral, por ello, al abrir formalmente una investigación penal, la prisión preventiva no debe aplicarse como pena anticipada, como era en el modelo inquisitivo, sin embargo, el requisito sustancial de la pena probable mayor de 4 años que aun mantiene el artículo $268^{\circ}$ del Nuevo Código Procesal Penal, mantiene esta práctica de pena anticipada, cuando se le argumenta al Juez que la pena a imponer será mayor de 4 años, se la está diciendo que la futura sentencia será una de 
Víctor Burgos Mariños - Apuntes para la interpretación constitucional del Código Procesal Penal

carácter efectiva, por lo tanto, tiene que aplicarse la prisión preventiva para garantizar la futura condena.

La oralidad y el sistema de audiencias, no solo se aplica al Juicio Oral, sino también a todas las decisiones trascendentes que el Juez debe tomar durante las etapas procesales previas al juicio oral. Ahora, la audiencia es una garantía de todos los ciudadanos que el Juez Penal decida, bajo los principios de oralidad, contradicción, inmediación y publicidad. Esta es la principal reforma que genera el cambio de prácticas procesales y administrativas, pues todo aquello que antes se resolvía por escrito, ahora se resuelve luego del debate contradictorio realizado en la audiencia.

El cambio de la justicia hacia la oralidad del Modelo Acusatorio, requiere de la configuración de un nuevo Despacho Judicial, que permita la consolidación de las nuevas prácticas, y la erradicación de las viejas prácticas. Sin embargo, la aplicación literal del artículo $135^{\circ}$ viene generando muchos expedientes, de copias de copias por cada requerimiento que haga la Fiscalía, lo que hace que se mantengan las viejas prácticas procesales y administrativas. Estas prácticas ya no tienen sentido en el Nuevo Modelo Acusatorio, pues el Juez ya no debe resolver por escrito, sino en audiencia, y lo que debería de hacer el Fiscal, es llevar sus pruebas a la audiencia para exhibirlas públicamente. La aplicación literal de esta norma, también impide la configuración del Nuevo Despacho, basado en la gestión de audiencias, y no en la gestión de expedientes.

La aplicación de la terminación anticipada como salida alternativa del proceso penal, tiene una serie de aspectos positivos para el imputado y el proceso mismo, así como para la víctima, sin embargo, la aplicación literal del artículo $468^{\circ}$ inciso 1, impide que pueda ser aplicado durante la etapa intermedia. En principio, en todo modelo acusatorio, la posibilidad de una salida alternativa siempre está presente, incluso hasta durante el juicio mismo. En nuestro Nuevo Código Procesal Penal también se prevé una salida alternativa, similar al de la terminación anticipada, conocida como proceso de conformidad, que en lo material, es similar a la Terminación Anticipada, pues implica la aceptación de los cargos, la reducción de la pena y el adelantamiento de la sentencia condenatoria. Asimismo, al ser derecho del imputado el juicio oral, un derecho disponible si ello lo favorece, como ocurre en la terminación anticipada, no se le puede impedir al procesado, renunciar al juicio oral a cambio de una reducción de pena ("pena justa"), durante la etapa intermedia.

El modelo acusatorio diseña un juicio oral basado en el debate contradictorio, donde cada una de las partes llega con su teoría del caso y despliega las técnicas de litigación oral, para poder demostrar al Juez, la verdad de su teoría 
Víctor Burgos Mariños - Apuntes para la interpretación constitucional del

Código Procesal Penal

del caso. Para ello debe darse prioridad al debate de las pruebas de cargo y las pruebas de descargo. Sin embargo, la aplicación literal de las normas que regulan el juicio oral en el Nuevo Código Procesal Penal, como la ubicación del acusado en juicio oral, las incidencias de conformidad y prueba nueva, así como el interrogatorio del acusado, como la primera actuación probatoria del juicio oral, debilitan la instalación de las nuevas prácticas. Por ejemplo, si el acusado se mantiene al centro de la sala de audiencias, va a seguir siendo objeto de prueba, pasando a segundo plano el debate contradictorio; si luego de escuchar la teoría del caso de la defensa, argumentando tesis de defensa, se le pregunta al acusado si acepta responsabilidad penal o no (proceso de conformidad) se debilita su posición de parte; si luego de la presentación de la teoría del caso, se admiten nuevas pruebas a ambas partes, entonces las teorías del caso van a sufrir modificaciones; la existencia del actual orden del juicio oral, que distancia la presentación del caso con la actuación probatoria, afecta la inmediación, concentración y debate contradictorio; conforme al modelo acusatorio, el debate contradictorio se inicia con la actuación de las pruebas del Ministerio Público para que demuestre su tesis acusatoria, sin embargo, la aplicación literal del artículo $375^{\circ}$, obligaría al Fiscal a iniciar la demostración de su teoría del caso, interrogando al acusado, quien de ninguna forma constituye un medio de prueba, y menos es prueba del Ministerio Público. Además, el interrogatorio del acusado como la primera actuación, afecta el derecho de defensa, pues el acusado debe declarar al final del debate contradictorio, para poder ejercer plenamente su defensa y contradecir las pruebas de cargo.

En el nuevo modelo con el solo escrito de apelación no es posible que se resuelva el recurso de apelación planteado, pues se hace necesario que la parte recurrente acuda a la audiencia de apelación, a fin de que se escuchen sus argumentos y se promueva el debate, bajo las reglas de la oralidad, inmediación y contradicción. $\mathrm{Y}$, es que con el nuevo modelo procesal, los Jueces resuelven previa audiencia, y no con el expediente. La parte apelante tiene el deber de acudir a su audiencia, caso contrario su recurso será rechazado. Esta es una regla procesal introducida por el sistema de recursos del modelo acusatorio y el Código Procesal Penal. Esta exigencia que se impone a la parte, de concurrir a su audiencia de apelación, no es un obstáculo insalvable que convierta el derecho a la instancia plural (acceso a todas las instancias), en algo inalcanzable, es una obligación impuesta a la parte, como lo es por ejemplo, el deber de fundamentación de su recurso, lo que en definitiva garantiza mejor, el derecho de defensa, y sanciona a la parte que es negligente, con su inadmisibilidad. Ahora, con el NCPP, si la parte recurrente no concurre a su audiencia de apelación, su recurso también 
Víctor Burgos Mariños - Apuntes para la interpretación constitucional del Código Procesal Penal

será declarado inadmisible. Esta regla está presente para el caso de apelación de sentencia condenatoria, el NCPP en el artículo $423^{\circ}$ inciso 3 establece de forma expresa que "si el acusado recurrente no concurre injustificadamente a la audiencia, se declarará la inadmisibilidad del recurso que interpuso. De igual manera se procederá si no concurre el Fiscal cuando es parte recurrente", así como también para el caso del recurso de casación de autos y sentencias, el recurrente deberá acudir a la audiencia de casación, caso contrario, su recurso será declarado inadmisible, así lo establece el artículo 431 inciso 2. La declaratoria de inadmisibilidad del recurso de apelación de auto, cuando la parte apelante no concurre, se encuentra ajustado a la regla rectora del sistema de recursos impugnatorios del Modelo Acusatorio basado en el sistema de audiencias, modelo que responde mejor al diseño constitucional del proceso penal, y que se ajusta a un principio de legalidad constitucional, pues la garantía del proceso predeterminado por ley en el modelo acusatorio, establece que "la parte debe acudir a la audiencia requerida por ella" "que es deber de las partes probar su pretensión en audiencia", y, "que los jueces en el NCPP no resuelven una apelación sin audiencia". Si bien la lectura literal de la norma que regula la apelación de autos no es compatible con el deber de la parte apelante de concurrir a la audiencia, la facultad de declarar inadmisible el recurso de apelación de auto por inconcurrencia de la parte apelante, si se encuentra expresamente recogido en el artículo 420 inciso 4, sobre trámite de la apelación de autos se precisa que "El auto en el que la Sala declara inadmisible el recurso podrá ser objeto de recurso de reposición, que se tramitará conforme al artículo 415", concordado con el inciso 5 "En la audiencia que no podrá aplazarse por ninguna circunstancia, se dará cuenta de la resolución recurrida, de los fundamentos del recursos, y acto seguido, se oirá al abogado del recurrente y a los demás abogados de las partes asistentes...". Efectivamente, la apelación de autos se resuelve previa audiencia, que una vez oralizada la resolución y el recurso, se oirá al abogado del recurrente. Como se podrá advertir, la norma impone el deber de concurrir de la parte recurrente, $y$, que la facultad de concurrir o no a la audiencia, es para las partes que no son recurrentes. Por lo que la sanción de inadmisibilidad resulta aplicable para el caso de apelación de autos.

En segunda instancia, el proceso penal también se desarrolla bajo las reglas del modelo acusatorio, donde toda apelación o casación, de auto o sentencia, se resuelve en audiencia y conforme a los principios de oralidad, contradicción, inmediación y publicidad, por ello, debe de evitarse la formación de expedientes judiciales como lo dispone el artículo $9^{\circ}$ del Nuevo Código Procesal Penal, y promover que las partes lleven sus pruebas a la audiencia. Además, debe de garantizarse plenamente el derecho a la doble instancia, para lo cual, debe de permitirse el desarrollo de la audiencia de apelación, 
Víctor Burgos Mariños - Apuntes para la interpretación constitucional del

Código Procesal Penal

aun si el acusado no concurre, pero si su abogado defensor, pues si se aplica literalmente el artículo 423 inciso 5, se puede declarar inadmisible su recurso de apelación, y la sentencia condenatoria puede quedar firme, a pesar que su Abogado Defensor acude a la audiencia.

Para hacer frente a los problemas suscitados por la aplicación literal de las normas que contienen rezagos inquisitivos, en varios distritos judiciales se ha acudido a la aplicación del Artículo X del Título Preliminar del Nuevo Código Procesal Penal, en concordancia con el artículo $138^{\circ}$ de la Constitución, que regulan la interpretación constitucional de las normas. De acuerdo a ello, los jueces deben de realizar una interpretación conforme al diseño Constitucional del Proceso penal, es decir, una interpretación constitucional que preserve los valores y principios fundamentales del Modelo Acusatorio Peruano. En todo caso, repito, que la interpretación sistemática y teleológica restringida del Art. 159.4 y parte destacada del Art. 166 de la Constitución despeja cualquier duda o confusión y prevalece el principio de coherencia normativa que, a su vez, sustenta la vigencia formal y real del Modelo Acusatorio. Más aún, téngase presente que desde de 1979 el Estado peruano ha consagrado como Principio Supremo de su ordenamiento jurídico el Principio de Constitucionalidad (que se sustenta en la concepción de la supremacía constitucional); en consecuencia, el Principio de Legalidad (general) tiene validez y eficacia, siempre que sea compatible con la Constitución (Mixán Mass, 2008).

\section{REFORMA PROCESAL PENAL, PRINCIPIO DE ORALIDAD $Y$ CONSTITUCIÓN}

El modelo que mejor responde a un diseño constitucional de proceso penal es el modelo acusatorio. El modelo acusatorio del Código Procesal Penal de 2004, propone un nuevo proceso penal basado en un sistema de audiencias, con oralidad, contradicción, inmediación y publicidad. El derecho a la presunción de inocencia del imputado y sus demás derechos, se garantizan mejor en una audiencia; el derecho de las víctimas a la tutela judicial efectiva, también se garantiza mejor en una audiencia; la transparencia e imparcialidad de los jueces se garantizan mejor en una audiencia; Es donde se garantiza un trabajo más profesional de jueces, abogados y fiscales; la audiencia es donde mejor se garantizan los derechos fundamentales. Por ello, el modelo acusatorio es el que mejor responde a las exigencias constitucionales del debido proceso. Para Chiovenda (1940:153) “... el proceso oral es, con mucho, el mejor de los dos y el que mejor conviene a la naturaleza y exigencias de la vida moderna, ya que sin comprometer en nada, antes bien, garantizando el acierto intrínseco de la decisión, proporciona ésta con mayor economía, sencillez y celeridad". 
Víctor Burgos Mariños - Apuntes para la interpretación constitucional del

Código Procesal Penal

El modelo acusatorio requiere de la sustitución de las prácticas basadas en la escrituralidad por prácticas basadas en la oralidad. El Modelo mixto inquisitivo se caracteriza por el predominio de la escrituralidad, los ritos y formalidades del procedimiento penal, su excesivo retardo, el lenguaje complicado de las resoluciones y escritos de los abogados. En este modelo, el juez trabaja encerrado en su despacho, ubicado generalmente, en la última oficina del Juzgado, lo que ha generado una subcultura de la corrupción y la mediocridad, como la forma "más práctica" de litigar los casos por parte de los abogados, y que involucra a todo el sistema desde el nivel policial. Sea que la corrupción se origine en el mal funcionario judicial o en el mal abogado, lo cierto es, que el procedimiento escrito crea las condiciones ideales para la corrupción y una práctica mediocre del derecho, que atenta contra los intereses de la recta administración de justicia. Incluso, las etapas orales de este modelo, son predominantemente escritas. En las audiencias de vista de la causa y del juicio oral, los jueces resuelven conforme al expediente, y las actuaciones orales no tienen mayor importancia. Cuando el Fiscal formula su acusación escrita afirma que "el delito y la responsabilidad penal ya estaban probadas fehacientemente con lo actuado en el Atestado Policial y la etapa de Instrucción Judicial" ${ }^{2}$. En este modelo escrito, el delito y la responsabilidad penal era "probada" en la etapa de investigación (con actos de investigación), y no en el juicio oral (actos de prueba). El juicio oral, se reduce a una mera formalidad, y a veces, a un acto mediático. El nuevo Código Procesal Penal al optar por la oralidad y el sistema de audiencias, exige el desarrollo de nuevas prácticas por parte de los operadores penales. Ahora, el Fiscal en su acusación escrita solicita al Juez de Investigación Preparatoria, la realización de un juicio oral para poder demostrar la existencia del delito y responsabilidad penal, y esto es así, porque es en el juicio oral donde se van a producir los verdaderos actos de prueba que van a sustentar, de ser el caso, una declaración legítima de la culpabilidad del imputado. Es en el juicio oral donde se declara la culpabilidad, y ya no en la investigación. Para Gimeno (1992:506), "una decisión tan importante como la reforma del sistema procesal

\footnotetext{
2 Tribunal Constitucional Del Perú. Sentencia del Exp. N. ${ }^{\circ}$ 9403-2006-PHC/TC:

http://www.tc.gob.pe/jurisprudencia/2007/09403-2006-HC.html : consultado el 09/02/2011. Según esta sentencia, las normas que regulaban las actuaciones del Ministerio Público al momento de acusar, bajo las reglas del Modelo Mixto Inquisitivo "Y, respecto de la actuación del Ministerio Público, la conclusión no podría ser de alcances menos categóricos, por ser la entidad encargada de conducir, desde su inicio, la investigación del delito (artículo 159, inciso 4, de la Constitución), siendo determinante la participación del Fiscal Superior, a quien, culminada la fase de instrucción, compete “(...) formular acusación sustancial si las pruebas actuadas en la investigación policial y en la instrucción lo han llevado a la convicción de la imputabilidad del inculpado; o meramente formal, para que oportunamente se proceda al juzgamiento del procesado, si abrigase dudas razonables sobre su imputabilidad" (artículo 92, inciso 4, del Decreto Legislativo N. ${ }^{\circ} 052$-Ley Orgánica del Ministerio Público-). En tal sentido, la opinión del Fiscal Superior es un factor de vital importancia para determinar la existencia de mérito para pasar a juicio oral".
} 
Víctor Burgos Mariños - Apuntes para la interpretación constitucional del

Código Procesal Penal

requiere como cuestión previa fijar la función que en el contexto socio-estatal vigente le corresponde al proceso penal, solo así puede individualizarse el norte que debe seguir la reforma. La reforma exige que las audiencias se conviertan en lo más importante del proceso penal. Para ello se debe sustituir al expediente y a sus viejas prácticas, por la audiencia y las nuevas prácticas, a la escrituralidad, por la oralidad.

La oralidad ha pasado de ser una característica de las formas del procedimiento a principio fundamental del proceso. La oralidad, según la doctrina clásica del procesal civil, fue considerada como parte de los principios relativos de la forma de los actos procesales, es decir, como un principio de tercera o cuarta categoría sin ningún entroncamiento con las garantías constitucionales del debido proceso. Tal doctrina empieza a evolucionar a partir de FairenGuillén (1988:481), quien en relación con la ZPO austriaca afirma, que si bien el principio de la oralidad aislado de otros tendría tan solo un simple carácter técnico, "ligado con los demás y al servicio de alguna categoría más importante del proceso -política- se puede elevar a pilar fundamental del mismo". En materia penal, la inclusión de la oralidad en los procesos escritos tiene repercusiones más intensas y directas con el respeto de los derechos fundamentales, pues en buena cuenta significa sustituir un proceso inquisitivo-autoritario, por uno de corte democrático basado en las garantías de oralidad, contradicción, inmediación y publicidad. Así, la oralidad en materia penal deja de ser un principio del procedimiento, y se convierte ahora, en un principio viabilizador del debido proceso. La oralidad, convierte a la audiencia en un valor con jerarquía constitucional, y en su principal contenido, pues ahora, con el NCPP, el imputado, el agraviado, el Fiscal y el tercero civil, tienen derecho a la audiencia previa. Es decir, el derecho a llevar sus pruebas y a ser escuchados en la audiencia, antes que el Juez resuelva su caso. Indudablemente, la oralidad también comprende al Juez, quien no podrá resolver sin previa audiencia, sino luego de haber escuchado lo debatido por las partes en la audiencia, y, en la audiencia, a través de decisiones orales. $Y$, es que como explicaremos a continuación, para que opere realmente la reforma procesal en nuestro país, los jueces deben resolver los casos con resoluciones orales.

La oralidad como estrategia de la implementación de la reforma procesal penal, ha dejado de ser vista como un aspecto formal del acto procesal, hoy la oralidad, además de principio viabilizador del debido proceso, es también una estrategia para la implementación de la reforma procesal penal. La oralidad como estrategia de implementación nos permite diseñar una estrategia de implementación destinada a erradicar el predominio de la escrituralidad, 
Víctor Burgos Mariños - Apuntes para la interpretación constitucional del Código Procesal Penal

para instalar el predominio de la oralidad. Sustituir las prácticas basadas en el expediente, por las prácticas basadas en la audiencia. Pues si las primeras se mantienen, será imposible concretar exitosamente la reforma procesal penal y la instauración del modelo acusatorio en nuestro país.

La oralidad es también un principio de la organización y gestión del nuevo despacho judicial. En efecto, otro aspecto clave en la reforma procesal, es la organización del Nuevo Despacho Judicial, el mismo que integra a su nueva concepción a la audiencia y a la división de trabajo entre lo administrativo y lo jurisdiccional. Efectivamente, el modelo acusatorio, basado en la oralidad, requiere de un diseño de Despacho Judicial que tenga a la audiencia, como su principal valor de organización y gestión, y no al expediente. La oralidad como principio de organización y gestión del nuevo Despacho, instaura una separación de roles, existe una Organización Administrativa cuya función es la de preparar las audiencias, y una Organización Jurisdiccional que tendrá como función, el de realizar las audiencias. Esta organización es la forma más eficiente que permite una rápida consolidación de las buenas prácticas administrativas y también jurisdiccionales. La separación de funciones es clave para consolidar la reforma procesal penal, y tiene su fundamento en la propia Constitución como ya se ha sostenido en líneas anteriores. Por ello debemos advertir, que los procesos de implementación en nuestro país deben de esforzarse en consolidar y respetar la separación de funciones, caso contrario, no se consolidará el sistema de audiencias, el despacho del viejo modelo inquisitivo permanecerá, manteniendo el trámite de papeles y del expediente, afectando con ello el diseño constitucional del proceso penal acusatorio.

La oralidad como valor de transparencia y fortalecimiento de la labor judicial, requiere de un trabajo en verdaderas audiencias, donde se garantice la presencia de las partes y la materialidad del principio de contradicción. En este tipo de audiencia tendrá sentido el trabajo más público de los jueces y de las partes. En efecto, el derecho de las partes a la audiencia previa, no es otro que el derecho a que el Juez resuelva su caso en dicha audiencia. Una decisión oral dictada en audiencia, en presencia de las partes y el público, hace más real este derecho, pues las partes escuchan del Juez, en lenguaje sencillo, la decisión judicial y sus fundamentos. No olvidemos, que las resoluciones escritas tienden más a ser ininteligibles a las partes, pues dedican más espacio a describir como se ha desarrollado el proceso, cuáles han sido los argumentos de las partes, o a justificar la adopción de alguna posición jurídico-dogmática, y hasta el adorno o lucimiento académico. Las decisiones orales comunican mejor las decisiones judiciales, garantizando una mayor transparencia y 
Víctor Burgos Mariños - Apuntes para la interpretación constitucional del

Código Procesal Penal

confiabilidad en el servicio de justicia. Las partes ya no echan la culpa a los jueces de su fracaso legal, y hay una gran disminución de quejas funcionales.

La oralidad como valor para la solución del conflicto penal, contribuye a solucionar el conflicto primario originado por el delito, promoviendo la presencia de las partes a la audiencia. Este hecho trascendental, materializado en la presencia física del autor y víctima, y el derecho a la defensa material que se les concede antes que resuelva el Juez, hace que el conflicto se reduzca a un debate de hechos y pruebas de las partes, cuya solución esté en función a ellas, por lo que cuando un Juez resuelve, no lo hace solo pensando en la consecuencia legal, sino también en dar la razón a la parte que demostró tener la verdad de su lado. La inclusión de las partes en la audiencia, el hecho de oírlas, y de consignar su aporte a la solución del caso, contribuye positivamente la solución del conflicto penal. Esto, lamentablemente nunca se ha logrado con los procesos escritos.

La oralidad como valor para generar eficiencia en el uso de los recursos, es otro de los aspectos positivos para optimizar los servicios de justicia en materia pena. En efecto, con el personal de un Juzgado del viejo modelo, pueden trabajar 4 Jueces del Nuevo Modelo; con el personal de una Sala Penal Liquidadora, pueden trabajar 6 Salas de Apelaciones; Cuando se dictan las resoluciones oralmente en audiencia por el Juez, ya no se necesitan de notificadores; la confusión de roles, genera repetición de actuaciones, copia de copias, en cambio, cuando hay separación de roles, el trabajo es más eficiente; en el viejo modelo los procesos demoraban años para concluir, ahora con el Nuevo Modelo se concluyen en días y meses; un minuto de oralidad equivale a 7 de escrituralidad. Resulta evidente entonces, que un modelo procesal basado en la oralidad optimiza los recursos del sistema judicial y brinda un servicio más eficiente.

La oralidad como baluarte en la lucha contra la corrupción judicial, es otro de los aportes que trae el nuevo modelo. La separación de roles entre lo administrativo y jurisdiccional, determina que el personal administrativo se dedique únicamente a preparar la audiencia, y ya no tenga el manejo del caso ni el proyecto de resolución judicial, que como efecto de la delegación de funciones ejercía, y que era el origen de la corrupción. La separación de roles en el Nuevo Modelo obliga a que sean los jueces y solo los jueces, quienes deban de resolver el caso penal, y la mejor garantía para ello, es que resuelvan oralmente en la misma audiencia. Con la erradicación de la delegación de funciones, se elimina esta mala práctica y se cierra uno de los más importantes escenarios corrupción en el viejo modelo. Además, el trabajo público del Juez 
Víctor Burgos Mariños - Apuntes para la interpretación constitucional del

Código Procesal Penal

y las partes en la Sala de Audiencias, elimina ese "corredor" entre la puerta del juzgado y la oficina del Juez que estaba al fondo, por el cual discurría con facilidad e impunidad los más oscuros intereses de la corrupción, sea que ésta se origine en el mal juez o en el mal abogado, dentro o fuera del juzgado. Ahora, con el Nuevo Modelo, ese "corredor" ha sido eliminado, pues ahora los jueces trabajan públicamente en las Salas de Audiencia y se garantiza así, una justicia más transparente.

\section{LA FORMA ORAL DE LAS RESOLUCIONES JUDICIALES FORMA PARTE DE LA GARANTÍA DE MOTIVACIÓN CONTENIDA EN EL ARTÍCULO 139 INCISO 5 DE LA CONSTITUCIÓN}

En el Pleno Regional sobre el NCPP de Arequipa, de Julio del 2009, se discutió si las resoluciones debieran dictarse verbalmente en audiencia y ser registrados en audio, y allí se produjo el debate sobre la forma como debía interpretarse el artículo 139 inciso 5 de la Constitución, que exige "la motivación escrita de las resoluciones judiciales en todas las instancias...". La mayoría se inclinó en realizar una interpretación evolutiva de la Constitución y no literal, pues en el contexto de la Constitución de 1979 y la 1993, el proceso era escrito y no oral, por eso la exigencia de la escrituralidad, más la verdadera garantía no estaba en su forma escrita, sino en el deber de motivación de la resolución. En dicho Pleno, se adoptó por MAYORÍA la siguiente CONCLUSIÓN PLENARIA: "El nuevo modelo acusatorio privilegia la oralidad. Las decisiones judiciales deben ser preferentemente orales, en especial aquellas que se dicten en audiencias preliminares. El registro de las mismas se encuentra en audio. Las actas de audiencia contienen una síntesis de lo actuado".

Meses más tarde, el Tribunal Constitucional respaldó esta línea de interpretación evolutiva de la garantía constitucional del deber de motivación, contenida en el artículo 139 inciso 5, pues en la sentencia recaída en el Expediente N$^{\circ}$ 029372009-PHC/TC-La Libertad, de fecha 25 de setiembre de 2009, revisando los audios de una resolución dictada oralmente, señaló "...no se ha acreditado la vulneración del derecho a la motivación de las resoluciones judiciales, ni de ningún otro derecho invocado, toda vez que la Primera Sala Penal de Apelaciones de la Corte Superior de Justicia de La Libertad ha cumplido con las exigencias del artículo $139^{\circ}$, inciso 5, de la Constitución Política, al haber motivado la resolución cuestionada de forma razonada y suficiente..." (el subrayado es nuestro). Esta doctrina jurisprudencial del Tribunal Constitucional, ha sido reiterada en numerosas sentencias que han llegado, como consecuencias de acciones de hábeas corpus contra autos judiciales dictados oralmente. 
Víctor Burgos Mariños - Apuntes para la interpretación constitucional del

Código Procesal Penal

Así, la sentencia en el Expediente $N^{\circ}$ 05260-2009-PHC/TC, el Tribunal Constitucional señaló que "...la necesidad de que las resoluciones judiciales sean motivadas es un principio que informa el ejercicio de la función jurisdiccional, y al mismo tiempo, un derecho constitucional de los justiciables. Mediante ella, por un lado, se garantiza que la administración de justicia se lleve a cabo de conformidad con la Constitución y las leyes (artículos 45. ${ }^{\circ}$ y $138 .^{\circ}$ de la Constitución Política del Perú) y, por otro, que los justiciables puedan ejercer de manera efectiva su derecho de defensa. Justamente, con relación al derecho a la debida motivación de las resoluciones, este Tribunal ha precisado que la Constitución no garantiza una determinada extensión de la motivación, por lo que su contenido esencial se respeta siempre que exista fundamentación jurídica congruente entre lo pedido y lo resuelto, y que, por sí misma, exprese una suficiente justificación de la decisión adoptada, aun si ésta es breve o concisa [...]" (STC N. ${ }^{0}$ 1291-2000-AA/TC. FJ 2)... Conforme se aprecia de la copia de audio remitida a este Tribunal (anexa en el cuadernillo del Tribunal Constitucional), la Resolución de fecha 7 de julio del 2009, que confirmó la Resolución de fecha 27 de febrero del 2009 (fojas 69), se encuentra debidamente motivada respecto de que con los argumentos planteados en el escrito de apelación y lo desarrollado en el proceso no se han desvirtuado la vinculación del beneficiario respecto del delito imputado; la pena privativa de la libertad superior a 5 años y el peligro de fuga".

Para la doctrina jurisprudencial del Tribunal Constitucional, las decisiones judiciales dictadas oralmente son compatibles con la garantía del deber de motivación contenida en el artículo 139 inciso 5, y que la forma escrita de las resoluciones no forma parte del contenido esencial de dicha garantía. Con ello se ha reconocido el valor, la necesidad y legitimidad de las resoluciones orales en el Modelo Acusatorio. Si nos sujetamos a la doctrina del Tribunal Constitucional, ya citada, no sería exigible ninguna forma en particular, sino tan solo el de verificar, una motivación coherente y suficiente. Justamente las decisiones orales no tienen una forma o apariencia externa en particular, lo que guarda relación con la tendencia antiformalista del Modelo Acusatorio. La motivación es coherente cuando la argumentación es estructurada mediante un razonamiento lógico. Para Mixán (1987:193), esto es, “...sin incurrir en contradicciones, en el desorden de ideas, en falacias, en una mera yuxtaposición numerativa de folios o de afirmaciones o negaciones formuladas mecanicistamente (sin derivar las respectivas significaciones probatorias) o en una frondosa, enrevesada y superficial acumulación de digresiones sin mayor relación con el caso a resolver". La coherencia de la motivación, también tiene que ver con el principio de congruencia. La motivación es suficiente, cuando responde coherentemente a las pretensiones planteadas por las partes. No 
Víctor Burgos Mariños - Apuntes para la interpretación constitucional del Código Procesal Penal

es exigible que el Juez responda a cada uno de los argumentos empleados por las partes, pues la motivación no exige "un diálogo con las partes" (STC 168/1987, español, y, STC Exp. N 1230-2002-HC/TC, peruano).

El sistema de audiencias facilita la delimitación de las pretensiones de las partes. Toda audiencia en el nuevo modelo, tiene la ventaja de delimitar concretamente la pretensión de la parte que solicita la audiencia, y también, de la parte adversaria. Sea un requerimiento fiscal o una solicitud de las otras partes, el debate y la información que se produzcan en la audiencia, se centrará al título de la audiencia. Por ejemplo, si es una audiencia de prisión preventiva, el debate se centrará al hecho si concurren o no los requisitos legales para su procedencia; si es una excepción de improcedencia de acción, el Juez decidirá si procede o no cerrar el proceso, según sea extintiva o dilatorio el medio técnico de defensa; si es un pedido de nulidad, se deberá centrar en demostrar si hubo o no trasgresión al debido proceso, etc. Finalmente, el debate contradictorio con la concurrencia de las partes, permite garantizar la coherencia de la decisión judicial, pues el Juez tendrá que dar la razón a quien demuestra tenerla en la audiencia respectiva. Se debe tener en cuenta que los debates en la audiencia pública, son principalmente sobre hechos y pruebas.

El principal reto del Juez es saber obtener información de la audiencia, para ello se requiere empezar a confiar en la audiencia y en el debate contradictorio. En los primeros meses de implementación esto es algo muy difícil, pues todavía se mantiene la dependencia al Expediente. Por mucho tiempo se ha confiado en el expediente, y ahora con el NCPP se debe confiar en la audiencia, lo cual no es fácil, ya que depende de múltiples factores. Esta confianza en algo nuevo como la audiencia tiene que construirse paso a paso. La experiencia en la implementación nos ha llevado a constatar, que si no suprimimos la presencia física del expediente de manos del Juez, no se dejará de depender de él, y eso a la postre, no permitirá consolidar a la audiencia, las partes no tendrán incentivos para acudir al debate, las resoluciones serán escritas, y todo seguirá igual que en el viejo modelo.

El Juez para obtener información de la audiencia y empezar a confiar en ella, podría seguir los siguientes pasos:

a) Acreditación de las partes

b) Delimitación del tema a debatir

c) Sustentación de la pretensión fiscal, mediante la afirmación de hechos y pruebas en las que se sustentan. 
Víctor Burgos Mariños - Apuntes para la interpretación constitucional del

Código Procesal Penal

d) Contradicción de la Defensa, que consiste en la fundamentación de su propia pretensión, y/o la desacreditación de la pretensión fiscal.

e) Réplica fiscal, dirigida a levantar desacreditación, y/o desacreditar pretensión de la defensa.

f) Dúplica de defensa, para levantar desacreditación.

g) Preguntas aclaratorias a las partes, y/o exhibición de la carpeta.

h) Defensa material del agraviado.

i) Defensa material del imputado.

j) Resolución oral, previo un receso, de ser necesario.

\section{DINÁMICA DE UNA AUDIENCIA PREVIA AL JUICIO ORAL: JUEZ DE GARANTÍAS}
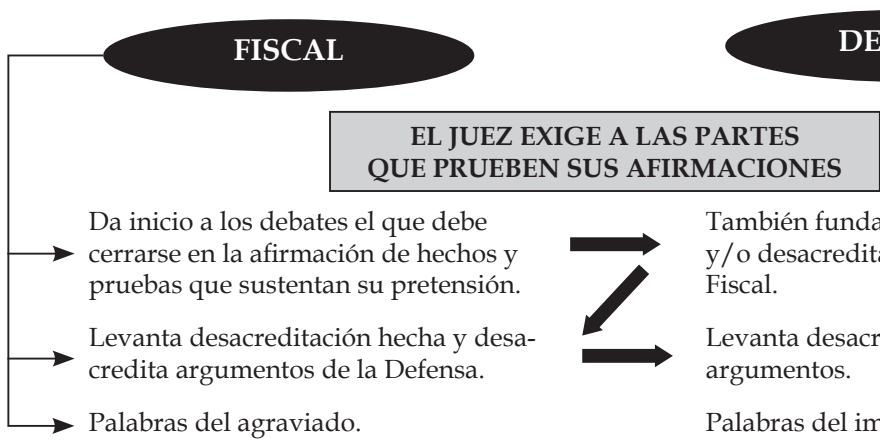

DEFENSA

\section{RESOLUCIÓN JUDICIAL}

DICTADA ORALMENTE

El contenido de la resolución oral deberá tener en su relato el siguiente orden:

1) La indicación clara y precisa del objeto o motivo de la audiencia y la norma a aplicar (premisa mayor)

2) Los hechos fijados como ciertos y creíbles por el Juez en la audiencia, y los elementos de convicción que respaldan el razonamiento (premisa menor).

3) Resolución judicial, expresión clara y precisa de la decisión (conclusión o consecuencia).

Este esquema es usado para dictar las resoluciones durante las audiencias distintas al juicio oral, es decir, para resolver los autos judiciales. Toda decisión transcendente durante el proceso penal, se dicta previa audiencia, por lo que 
Víctor Burgos Mariños - Apuntes para la interpretación constitucional del

Código Procesal Penal

debe conforme al artículo 8 inciso 4, el Juez “... resolverá inmediatamente...o en todo caso en el plazo de 2 días", la forma que sugiere el Código aquí, es la forma de una decisión oral. En efecto, la regla en el caso de los autos judiciales, es la resolución oral, sin embargo, hay que admitir la necesidad en algunos casos - por su complejidad y dificultad- se acuda a la resolución escrita. Pero, no hay duda que la forma como se debe organizar el despacho judicial y se debe predisponer la práctica procesal, es en base a la oralidad, con práctica oral de las partes y con decisiones orales del Juez. No se puede mantener la organización del despacho y la práctica escrita, solo en base a la excepción, pues no resulta coherente con el proceso de reforma.

En el caso de las sentencias, si bien la regla en el Código Procesal Penal es la sentencia escrita, por las mismas razones que sustentan la oralidad podríamos afirmar, que no hay impedimento para dictar sentencias orales -en principio para los casos fáciles-. Además, consideramos, que una práctica de las sentencias orales pueden aportar positivamente a la determinación de la pena concreta. Efectivamente, una de las constataciones que viene haciendo en la práctica del Nuevo Código Procesal Penal es la falta del debate sobre la pena. En los juicios orales, como consecuencia del desarrollo de las técnicas de litigación oral, el debate se ha centrado entre las teorías del caso de las partes, las que están siempre dirigidas a discutir la culpabilidad. Además, dentro del juicio oral, no existe un espacio previsto para debatir la pena y demás consecuencias jurídico penales, por lo que su imposición viene siendo subjetiva y sin motivación. Si se asumiera como práctica que los jueces, luego del debate contradictorio del juicio oral, pudieran dictar in voce la sentencia, en caso sea declaratoria de culpabilidad, se podría reabrir el debate para discutir la pena, y así contar con los mayores elementos de convicción posibles para individualizar la pena. Lamentablemente esto no ocurre, pues tanto los alegatos de inicio como de cierre, se refieren a su teoría del caso, por lo que una vez concluido el debate, se escucha la defensa material del agraviado y el imputado, e inmediatamente se suspende la audiencia para emitir sentencia escrita, sin que se halla debatido la pena a imponer y sin que se hayan incorporado pruebas a la audiencia, que ayuden al Juez a individualizar la pena, en los términos más objetivos y razonables, como es la pena justa.

\section{CONCLUSIONES}

De los resultados de la investigación se llegó a las siguientes conclusiones:

1. La reforma de la justicia penal requiere que se den las condiciones necesarias para la sustitución de las viejas prácticas inquisitivas, por las 
Víctor Burgos Mariños - Apuntes para la interpretación constitucional del

Código Procesal Penal

nuevas prácticas acusatorias, siendo una de esas condiciones la existencia de una legislación interna favorable al Modelo Acusatorio, tanto al nivel legal como constitucional.

2. En el Perú no se hizo una reforma integral de la legislación orgánica ni de la Constitución, para generar las condiciones favorables para garantizar una correcta implementación del Nuevo Código Procesal Penal y el Modelo Acusatorio, tal como se hizo en Chile y Colombia. Esto ha generado interpretaciones contradictorias en los diferentes distritos judiciales en los que viene operando el Nuevo Código Procesal Penal, lo que ha llevado a que algunos Distritos Judiciales tiendan a mantener las viejas prácticas y a impedir la instalación de las nuevas prácticas del Modelo Acusatorio.

3. Existe en el Nuevo Código Procesal Penal, normas que mantienen rezagos inquisitivos, que favorecen las viejas prácticas, el predominio de la escrituralidad y el expediente, la delegación de funciones, que se contraponen al Nuevo Modelo Acusatorio, en especial, al sistema de audiencias (juicio oral) y al diseño de una investigación eficiente basada en la coordinación entre la Policía y Fiscalía.

4. La interpretación literal de las normas del Nuevo Código Procesal Penal, que mantienen rezagos inquisitivos, mantienen las viejas prácticas procesales, así como la cultura inquisitiva, lo que no hace posible consolidar plenamente el nuevo proceso basado en la oralidad y el sistema de audiencias, y la separación de funciones entre lo administrativo y jurisdiccional.

5. La Constitución de 1993 al adoptar un Modelo de corte Acusatorio, permite la interpretación constitucional de las normas del Nuevo Código Procesal Penal, conforme al artículo $138^{\circ}$ constitucional y al artículo $\mathrm{X}$ del Título Preliminar del Nuevo Código Procesal Penal. Concluimos que si se aplica la interpretación constitucional sobre las normas que contienen rezagos inquisitivos, permitirá erradicar las viejas prácticas, y, crear las condiciones favorables para que en la realidad y en el día a día del proceso penal, se consolide el Modelo Acusatorio en el Perú.

6. Para uniformar los diferentes criterios que puedan existir respecto a la interpretación constitucional de las normas que contienen rezagos inquisitivos del Código Procesal Penal, al final resulta necesaria una reforma de todo el sistema legal, a fin de que se adecuen al Modelo acusatorio, una reforma que comprenda la Constitución, la legislación orgánica y el propio Código Procesal Penal. 
Víctor Burgos Mariños - Apuntes para la interpretación constitucional del

Código Procesal Penal

7. Realizar un programa de monitoreo constante del proceso de implementación, sistematizando la información de las diferentes Cortes Superiores de Justicia que vienen aplicando el Nuevo Código Procesal Penal, y evaluar el progreso de la instalación de las nuevas prácticas del Modelo Acusatorio.

8. La oralidad es hoy un principio viabilizador del debido proceso penal. La oralidad es un factor determinante para la estrategia de implementación de la reforma procesal penal. La oralidad es un principio de organización y gestión del nuevo despacho judicial. La oralidad contribuye a la lucha contra la corrupción, así como a la transparencia y eficiencia de la justicia. Las resoluciones judiciales orales son compatibles con la Constitución y la garantía del deber de motivación del artículo 139 inciso 5.

9. Las sentencias orales pueden contribuir al debate sobre la pena a imponer.

10. La oralidad necesita ser fortalecida, para garantizar plenamente la reforma procesal penal en el Perú. 